\title{
Analysis of Parents, Teachers and Students' Perception of Teaching Profession in South-West Nigeria
}

\author{
Dr Lawal B. O. \\ Department of Teacher Education, Faculty of Education \\ University of Ibadan, Ibadan, Nigeria \\ Tel: 234-803-376-4494_E-mail: olubodelawwy@yahoo.com
}

Received: June 27, 2011

Accepted: August 10, $2011 \quad$ Published: January 1, 2012

doi:10.5539/ass.v8n1p119

URL: http://dx.doi.org/10.5539/ass.v8n1p119

\begin{abstract}
This study investigated the perception of the teaching profession among the parents, teachers and secondary school students in Southwestern Nigeria. Four null hypotheses were tested at 0.05 level. Three potent instruments: Teacher perception of Teaching Profession Questionnaire (TPTPQ), Parent Perception of Teaching Profession Questionnaire (PPTPQ) and Students Perceptions of Teaching Profession (SPTPQ), were validated by the Department of teacher Education for content and construct validity. The test retest reliability coefficient yielded the reliability indices of $0.85,0.81$ and 0.79 respectively. The instruments were administered on 170 sample size: (50) parents, (60) teachers and (60) students. Inferential statistics of t-test and Analysis of Variance at 0.05 level of significance were used to test the hypotheses. The result revealed that there is significant differences in the way the participants perceive teaching profession $(\mathrm{N}=60 \mathrm{X}=2.047, \mathrm{SD}=1.137),(\mathrm{N}=60$ $\mathrm{X}=1.943, \mathrm{SD}=1.007)$ and parents $(\mathrm{N}=50, \mathrm{X}=1.698, \mathrm{SD}=0.661)$. It is recommended among other things that government should take the training and retraining of teachers more seriously.
\end{abstract}

Keywords: Teaching profession, Teachers, Parents, Students, Perception

\section{Introduction}

Education is the key to participation in the highly competitive global economy of the $21^{\text {st }}$ century based on technological revolution, communication and transfer of information as well as major changes in production, transport, distribution and the economic value of knowledge. In other words, education is the fulcrum of modern day socio-political and economic development. The binding relationship among education, economy and society is interactive. To this end, the teacher plays a pivotal role in the educational development of any society and nation (Ololube, 2004). It has been said that no nation can grow beyond the quality of its education (teachers) and that a nation can only develop meaningfully and attain professionalism through a virile teaching profession (Obemeata, 1999).

Teaching is one of the oldest of human activities or professions because in those days, parents, elders in the community, religious leaders and other adults took it upon themselves to teach the young ones how to speak, act and, or, perform any other activity that might be required of them. Hence the teacher was seen as an important personality in the society. As important and sensitive as teaching is in the society, there have been divergent views held by people in the society about teaching. These divergent views however have influenced the perception that people have about teaching in the society.

For instance, teaching has been seen as an attempt to bring about effective and desirable change in learners and the education system through the use of various strategies (Adeyemi 2001, Dada 1999). This implies that teaching is not restricted to just a single activity but a variety of activities some of which are quite distinct from one another. Thus teaching is seen as a body of actions that is intended to bring about learning through conscious and deliberate efforts by a matured or experienced person (Akinpelu, 1981).

This was why in the 1950s through the early 1980s teachers and the teaching profession were accorded high status in the society because they performed their roles in promoting national development with high sense of efficiency and responsibility. This high sense of commitment has been attributed to three major factors namely; their good social status, economic status and conducive working environment (Achimugu, 2005). Teachers at 
that time were greatly honoured, dignified and highly respected by parents in particular and the society at large. The teacher was seen as a custodian of knowledge and an influential and inspiring personality in the society. He was rated and respected over and above other professionals such that some parents would want their children to become teachers. Thus the desire to become teachers in those days was high among the people.

However, events over the years have shown that the status and perception of teachers by the society and the teaching profession in Nigeria and many other countries of the world have nosedived (Hall and Langton, 2006; Hargreaves et al, 2007; Hoyle 2001). This low status and perception of teachers and the teaching profession could be attributed to the fact that the social origins of teachers and the environment of teaching and learning are seriously impoverished (Kottler and Stanley, 2000). That the various segments of the society have different perceptions of teachers and the teaching profession is not in doubt.

In a survey conducted among media houses, teachers, parents and teaching assistants in England, Hargreaves et al (2006) found that while the majority of the general public surveyed considered the teaching profession to be quite an attractive career due largely to an attractive salary package, the media's perception of teaching is more of a profession deserving some sympathy. Even among the general public that viewed teaching as an attractive career, a good number of them $(32 \%)$ still regarded teaching as unattractive.

In spite of the many studies that have been conducted and opinions that have been made (Hargreaves et al 2007, Hargreaves et al 2006, Hoyle 2001 among others) on the perception of teachers, parents and students of the teaching profession, there still exist divergent views of teaching in view of the efforts of governments at all levels and the private sector in improving the status of teaching. It has therefore become imperative to investigate the perception of parents, teachers and students of the teaching profession.

Specifically, this study set out to determine:

- $\quad$ whether there is a difference in the perception of parents and teachers of the teaching profession;

- $\quad$ if there is a difference in the perception of teachers and students of the teaching profession; and

- the difference in the perception of parents and students (if any) of the teaching profession;

- the difference in the perception of parents, teachers and students (if any) of the teaching profession.

The researcher is of the belief that the outcome of this study would expand the body of knowledge on issue of teaching as a profession. The study would be an eye opener to the perception of various stakeholders (parents, teachers, students etc) on the teaching profession.

\section{Review of the related literature}

Salami (2001) identified the following as some of the problems militating against the teaching profession in Nigeria; (a) the social status of entrants and practitioners (b) inability of the teachers to have a powerful association to control entry $(\mathrm{C})$ the non-existence of a professional body that can discipline offenders among the teachers (d)lack of sponsored training to update the knowledge of teachers.

In the same vein, Viatonu (2004) gave the following as some of the major problems facing teaching profession; (a) the nature of teachers (b) the background of teachers (c)the reward system for teachers (d) absence of a powerful teachers association (e) the physical appearance of some teachers particularly in primary schools. He advised that those problems should be addressed in order to enhance the status of teaching profession in Nigeria.

While contributing to the concept of teaching profession, Ezewu (1983) identified the following as the characteristics of a profession; (a) members must be specially prepared for the job (b) members should practice their profession freely (c) members should have a code of conduct that will guide their practice (d) members should have well-spelt out conditions of service (e) members should have an association (f) members and the profession should enjoy equal recognition with other professions. Like others, he finally listed the following as some of the problems facing the profession in the Nigerian society; (a) the number of teachers (b) personal benefit (c) external administration (d) internalization of training.

In his own contribution, David (2001), traced the evolution of teaching profession in Nigeria to the establishment of the first teacher training college by the church missionary society at Abeokuta in 1859. According to him, other churches joined in the establishment of their teacher training constitutions. He observed that even though teachers were faced with problems, the teaching profession in Nigeria has been able to achieve some degree of professionalism. For example Uche et al (1998) in their contribution to the concept of teaching profession, noted that recruitment of competent and committed individuals into the teaching profession has been a problem. According to them, this problem is as a result of teaching being in competition with other professions. They 
therefore advised that, government should recruit teachers among those that are interested in teaching and those that are academically good and committed to the progress of the children among other things.

\section{Methodology}

\subsection{Research design}

The study adopted the descriptive research design. This research design, according to Viatonu and Jegede (2007) is the most appropriate in that it is used to collect detailed and factual information that describe existing phenomenon and analyses, records, interpretes and explains events as they exist.

\subsection{Population and sample}

The population of the study consisted of parents, teachers and secondary school students in Southwest Nigeria. The sample was made up of one hundred and seventy (170) respondents selected using the purposive sampling technique. The sample included fifty (50) parents, sixty (60) teachers and sixty (60) secondary school students from Lagos, Ogun and Oyo States in Southwest Nigeria. The parents consisted of ministry officials, civil servants, traders, artisans in the 3 states.

\subsection{Instrumentation}

The instruments used for the study were three self-structured questionnaires. These are the Teachers' Perception of Teaching Profession Questionnaire (TPTPQ), Parents' Perception of Teaching Profession Questionnaire (PPTPQ) and Students' Perception of Teaching Profession Questionnaire (SPTPQ). Each of the questionnaires consists of two parts, A and B. Section A elicited demographic information of the respondents while Section B was designed in a modified four point Likert scale to determine the perception of teachers, parents and students on teaching as a profession.

\subsection{Validity and reliability of the instrument}

The three instruments (TPTPQ, PPTPQ and SPTPQ) were validated by colleagues in the Department of Teacher Education, University of Ibadan for content and construct validity. The Cronbach alpha method was used and Pearson Product Moment Correlation Coefficient was also used to analyse it yielding reliability indices of 0.85 , 0.81 and 0.79 respectively.

\subsection{Procedure for data collection}

The instruments were administered by the researcher to secondary school teachers, students and parents (which include the government workers, traders, artisans etc) in each state. The schools selected in Lagos State were Odo-Obara High School, Maryland Comprehensive High School and Epe Grammar School. In Ogun State, the schools selected were Oke-Ona Grammar School, Salawu Abiola Comprehensive High School and Asero High School while in Oyo Sate, Ibadan Grammar School, Ibadan, Awe High School, Awe and Arolu Grammar School Ogbomoso were selected.

\subsection{Hypotheses}

The following hypotheses were formulated and tested at 0.05 level of significance:

$\mathrm{H}_{1}$ : There is no significant difference between the perception of parents and teachers of the teaching profession in Southwest Nigeria.

$\mathrm{HO}_{2}$ : There is no significant difference between the perception of parents and students of teaching as a profession in Southwest Nigeria.

$\mathrm{HO}_{3}$ : There is no significant difference between the perception of teachers and students of teaching profession in Southwest Nigeria.

$\mathrm{HO}_{4}$ : There is no significant difference in the perception of parents, teachers and students of teaching profession in Southwest Nigeria.

\section{Results}

Data generated from the study were analysed using both descriptive and inferential statistical tools. The descriptive analysis used include frequency and percentages to analyse the demographic characteristics of the respondents while inferential statistics of t-test and Analysis of Variance (ANOVA) at 0.05 level of significance were used to test the hypotheses.

From the analysis in table 4 , there is a significant mean difference between parents $(\mathrm{N}=50, \mathrm{X}=1.698, \mathrm{SD}=$ $0.661)$ and teachers $(\mathrm{N}=60, \mathrm{X}=2.047, \mathrm{SD}=1.137)$ in their perception of teaching as a profession. This implies that teachers perceived teaching as a profession higher than the parents. Since the calculated t-value (15.115) is 
greater than the table value (1.96), the null hypothesis which states that there is no significant difference between the perception of parents and teachers of teaching as a profession in Southwest Nigeria is hereby rejected.

Table 5 below reveals a significant mean difference between parents $(\mathrm{N}=50, \mathrm{X}=1.698, \mathrm{SD}=0.661)$ and students $(\mathrm{N}=60, \mathrm{X}=1.843, \mathrm{SD}=1.007)$ in their perception of teaching as a profession. This implies that students had a higher perception of teaching as a profession than the parents. The calculated t-value (14.004) obtained was also greater than the table value (1.96). Thus, the null hypothesis which states that there is no significant difference between the perception of parents and students of teaching as a profession in Southwest Nigeria is rejected.

The analysis in table 6 shows that there is a significant mean difference between teachers $(\mathrm{N}=60, \mathrm{X}=2.047, \mathrm{SD}$ $=1.137)$ and students $(\mathrm{N}=60, \mathrm{X}=1.843, \mathrm{SD}=1.007)$ in their perception of teaching as a profession. The implication of this is that teachers perceived teaching as a profession better than students with the calculated t-value (17.798) which is greater than the table value (1.96). Therefore, the null hypothesis which states that there is no significant difference between the perception of teachers and students of teaching as a profession in Southwest Nigeria is hereby rejected.

The analysis on table 7 reveals that all the three categories of stakeholders sampled in this study (parents, teachers and students) perceived teaching as a profession. However, teachers' $(\mathrm{N}=60, \mathrm{X}=2.047, \mathrm{SD}=1.137)$ perception of teaching is better and higher than students' $(\mathrm{N}=60, \mathrm{X}=1.843, \mathrm{SD}=1.007)$ and parents' $(\mathrm{N}=50$, $\mathrm{X}=1.698, \mathrm{SD}=0.661)$.

\section{Discussion}

Based on the results of this study, it was revealed that there is a significant difference in the way people in the study (such as parents and teachers) perceive teaching as a profession. While some studies (Achimugu, 2005) have shown a positive and better perception of teaching as a profession others (Hall and Langton 2006) have seen teaching as a low status job. The implication of this finding is that some parents who formed part of the sample used for this study (civil servants, business men and women etc) who are in a better position to positively project teaching as a profession have probably looked down on teachers and the teaching profession.

The study also revealed a significant difference between the perception of parents and students of teaching as a profession. In other words, differences in biological status (whether children/students or parents) create a significant difference in their perception of teaching as a profession. Interestingly however, the mean scores of parents (1.698) and students (1.843) showed that the latter (students) have a better and greater perception of teaching as a profession than the parents. This tends to corroborate an earlier study (Hargreaves et al, 2007) in which parents and other associated groups persistently perceived teaching as a less rewarding profession.

Furthermore, the study revealed that there is a significant difference between the perception of teachers and students of the teaching profession. The mean scores for teachers (2.047) and students (1.843) were an indication that teachers (the practitioners) perceived the teaching profession better and more positively than students. This finding is at variance with an earlier study (Hargreaves et al 2007) which revealed that teachers perceived their profession as a low status job.

The study further revealed that all the three (3) categories of stakeholders sampled have a common perception of teaching: that teaching is a profession. However, the perception of teachers $(\mathrm{N}=60, \mathrm{X}=2.047, \mathrm{SD}=1.137)$ of teaching as a profession is higher and greater than the students' $(\mathrm{N}=60, \mathrm{X}=1.843, \mathrm{SD}=1.007)$ and parents' $(\mathrm{N}$ $=50, \mathrm{X}=1.698, \mathrm{SD}=0.661$ ).

\section{Conclusion and recommendations}

That teaching is a profession in Nigeria is not in doubt. However, when compared to other professions like law, engineering and medical professions, teaching continue to enjoy low esteem and professional autonomy in the country. This is perhaps evident in the yearly University Matriculation Examination (UME) and Monotechnic/Polytechnic and Colleges of Education of Education Examination (MPCE) now Unified Tertiary Matriculation Examination (UTME) where candidates choose courses in teacher education programme (Faculty of Education and Colleges of Education) as a last resort. Teachers who are the practitioners do not seem to want their children and or wards to choose teaching as a profession. This might not be unconnected with the unattractive reward system, low self esteem among other factors (Viatonu, 1999).

Based on the findings of this study, it is hereby recommended that requirements for admission into teacher education programme should be geared towards professionalism of the individual teacher. The misconception that teaching is an all-comers job should be corrected by employing people with only professional qualifications to teach. 
The society at large and individuals in particular should change their attitude towards teachers and the teaching profession. A situation whereby the society looks down on teachers in every area of life is not encouraging. The government should help matters by according teachers high priority in the scheme of things. A situation whereby teachers at all levels of education have to embark on industrial actions before they get government's recognition does not augur well not only for the education system but also for the socio-economic development of the country.

The Teachers' Registration Council (TRC) should be more alive to its responsibilities by ensuring that only certified and registered members are allowed to practise. Any "teacher" that is not registered should not be allowed to practise. This is moreso when it is common knowledge that non members of the Institute of Chartered Accountants of Nigeria (ICAN) and Association of National Accountants of Nigerian (ANAN) are not allowed to practice accounting by the government.

Government should take the training and re-training of teachers more seriously. To this end, government should sponsor more serving teachers on in-service training/higher professional and educational development. In the alternative, government should provide the enabling environment for teachers to go on self development by granting them study leave with pay and ensuring that their newly acquired certificates are used to their benefits.

The present study was conducted in only three states of the Southwestern Nigeria (Lagos, Ogun and Oyo). Therefore, more empirical evidence will be required from more states in the Southwest geopolitical zone of Nigeria before ample generalization can be made. In the light of this, it is suggested that a similar but more elaborate study be conducted using a larger sample and covering more states in the Southwest of Nigeria.

\section{References}

Achimugu, L. (2005). The Agonies of Nigerian Teachers. Lagos: Heineman Educational Book (Nig) Plc.

Adeyemi, B.G. (2001). Strategic Manpower Development in Nigeria: New Challenges and Directions. Education and Society, 17(3).

Akinpelu, J.A. (1981). An Introduction to Philosophy of Education. London: Macmillan Publishers.

Dada, A. (1999). The Teacher and the Curriculum. Ibadan: Tejama General Ent.

David E. Eddie. (2001). Introduction to Teacher Education for higher institutions. Uyo, Abbnny Educational publishers.

Ezewu E. (1983). Sociology of Education. Lagos, Longman Group Limited.

Hall, D. and Langton, B. (2006). Perception of the Status of Teachers. New Zealand: Ministry of Education.

Hargreaves, L., Cunningham, M., Everton, T., Hansen, A., Hopper, B., McLintyre, D., Maddock, M., Mukherjee, J., Peil, T., Rouse, M., Turner, P. and Wilson, L. (2006). The Status of Teachers and the Teaching Profession: Views from Inside and Outside the Profession: Interim Findings from the Teacher Status Project. Research Report 755. London: Department for Education Skills (DES).

Hargreaves, L., Cunninghman, M., Hansen, A., McLintyre, D. and Oliver, C. (2007). The Status of Teachers and the Teaching Profession in England. London: Department for Education Skills.

Hoyle, E. (2001). Teaching: Prestige, Status and Esteem. Educational Management and Administration, 29(2), 139-152.

Kottler, J.A. and Stanley, J.Z. (2000). On Being a Teacher. The Human Dimension. California: Crown Press.

Obemeata, P.O. (1999). Gateway to Teaching. Dubuqu: WMC Brown.

Ololube, N.P. (2004). Professionalism: An Institutional Approach to Teacher's Job Effectiveness in Nigerian Schools. A paper presented at the $7^{\text {th }}$ International Conference, September 23-25.

Salami, N. (2001). Sociology of Education. Ibadan, Olu-Akin publishers

Uche, U.W, and Onyemerekeya, C.C. (1998). Ezi-Abba. Nuel Centi publishers and Academic press Ltd.

Viatonu, O. (1999). Improved Teachers' Qualification and Social Perception: Sine Qua Non for Full Professionalism of Teaching in Nigeria. Journal of Education for National Development, 2(1\&2), 71-78.

Viatonu, O. (2004). Sociology of Education. Ijebu-Ode, Lucky Odoni (Nig) Enterprises.

Viatonu, O. and Jegede, A.A. (2007). A Comparative Analysis of Perception of Students and Academic Staff Toward Factors Associated with Cultism in Tertiary Institutions in Lagos State. Pakistan Journal of Social Sciences, 4(5), 667-671. 
Table 1. Teachers' Demographic Information

\begin{tabular}{|l|l|l|l|}
\hline \multicolumn{1}{|c|}{ Gender } & Educational Qualification & \multicolumn{1}{|c|}{ Teaching Experience } & \multicolumn{1}{|c|}{$\begin{array}{c}\text { Teachers' other } \\
\text { sources of income }\end{array}$} \\
\hline $\mathrm{M}=23(38.3 \%)$ & $\mathrm{NCE}=25(41.7 \%)$ & $\leq 1 \mathrm{yr}=14(23.3 \%)$ & Yes $=44(73.3 \%)$ \\
$\mathrm{F}=37(61.7 \%)$ & $1^{\text {st }}$ Degree $=22(36.7 \%)$ & $1-3 \mathrm{yrs}=12(20 \%)$ & No $=16(26.7 \%)$ \\
& PGDE $=09(15 \%)$ & $4-7 \mathrm{yrs}=3(5 \%)$ & \\
& M.A./M.Ed. $=02(3.3 \%)$ & $8-10 \mathrm{yrs}=10(16.7 \%)$ & \\
& Ph.D. $=02(3.3 \%)$ & $>10 \mathrm{yrs}=21(35 \%)$ & \\
\end{tabular}

Table 2. Parents' Demographic Information

\begin{tabular}{|l|l|l|}
\hline \multicolumn{1}{|c|}{ Parents Gender } & \multicolumn{1}{c|}{ Educational Background } & \multicolumn{1}{c|}{ Parents' Occupation } \\
\hline $\mathrm{M}=16(32 \%)$ & Primary $11(18.33 \%)$ & Unemployed $=6(10 \%)$ \\
& Secondary $39(65 \%)$ & Artisan $=11(18.33 \%)$ \\
& Tertiary $10(16.67 \%)$ & Govt. workers $=36(60 \%)$ \\
& & Business $=2(3.33 \%)$ \\
& & Politician $=1(1.67 \%)$ \\
& & Industrialist $=3(5 \%)$ \\
& & Others $=1(1.67 \%)$ \\
\hline
\end{tabular}

Table 3. Students' Demographic Information

\begin{tabular}{|l|l|l|l|}
\hline \multicolumn{1}{|c|}{ Gender } & \multicolumn{1}{c|}{ Class Distribution } & \multicolumn{1}{c|}{ Field of Study } & \multicolumn{1}{c|}{ Students' Performance } \\
\hline $\mathrm{M}=43(71.4 \%)$ & $\mathrm{SSS} 1=20(33.3 \%)$ & Arts $=13(21.7 \%)$ & Poor $=5(8.3 \%)$ \\
$\mathrm{F}=17(28.3 \%)$ & $\mathrm{SSS} 2=25(41.7 \%)$ & Commercial $=39(65 \%)$ & Average $=29(48.3 \%)$ \\
& $\mathrm{SSS} 3=15(25 \%)$ & Sciences $=8(13.35)$ & $\begin{array}{l}\text { Good }=20(33.3 \%) \\
\text { Very Good }=6(10.1 \%)\end{array}$ \\
\hline
\end{tabular}

Table 4. T-test Analysis of Parents and Teachers' Perception of Teaching as a Profession

\begin{tabular}{|c|c|c|c|c|c|c|c|c|}
\hline Groups & $\mathbf{N}$ & $\mathbf{X}$ & SD & df & t-cal & t-tab & P & Decision \\
\hline Parents & 50 & 1.698 & 0.661 & 108 & 15.115 & 1.96 & 0.05 & $\mathrm{H}_{0}$ rejected \\
\hline Teachers & 60 & 2.047 & 1.137 & & & & & \\
\hline
\end{tabular}

$\mathrm{t}$-cal $=15.115, \mathrm{t}$-tab $=1.96, \mathrm{df}=108, \mathrm{P}<0.05$

Table 5. T-test Analysis of Parents and Students' Perception of Teaching as a Profession

\begin{tabular}{|c|c|c|c|c|c|c|c|c|}
\hline Groups & $\mathbf{N}$ & $\mathbf{X}$ & SD & df & t-cal & t-tab & P & Decision \\
\hline Parents & 50 & 1.698 & 0.661 & 108 & 14.004 & 1.96 & 0.05 & $\mathrm{H}_{0}$ rejected \\
\cline { 1 - 6 } Students & 60 & 1.843 & 1.007 & & & & & \\
\hline
\end{tabular}

t-cal $=14.004$, t-tab $=1.96, \mathrm{df}=108, \mathrm{P}<0.05$

Table 6. T-test Analysis of Teachers and Students' Perception of Teaching as a Profession

\begin{tabular}{|c|c|c|c|c|c|c|c|c|}
\hline Groups & $\mathbf{N}$ & $\mathbf{X}$ & SD & df & t-cal & t-tab & P & Decision \\
\hline Teachers & 60 & 2.047 & 1.137 & 59 & 17.798 & 1.96 & 0.05 & $\mathrm{H}_{0}$ rejected \\
\cline { 1 - 5 } Students & 60 & 1.843 & 1.007 & & & & & \\
\hline
\end{tabular}

$\mathrm{t}$-cal $=17.798, \mathrm{t}$-tab $=1.96, \mathrm{df}=59, \mathrm{P}<0.05$

Table 7. Analysis of Variance (ANOVA) of the Perception of Parents, Teachers and Students on Teaching Profession

\begin{tabular}{|c|c|c|c|c|c|c|}
\hline Regression & \multicolumn{5}{|c|}{ ANOVA } \\
\hline Model & & $\begin{array}{c}\text { Sum of } \\
\text { Square }\end{array}$ & df & $\begin{array}{c}\text { Mean } \\
\text { Square }\end{array}$ & F & Sig \\
\hline $\mathrm{R}=.896$ & Regression & 37.548 & 2 & 18.774 & 96.207 & 0.05 \\
\hline $\mathrm{R}^{2}=.804$ & Residual & 9.172 & 47 & 7.195 & & \\
\hline Adjusted R $\mathbf{R}^{2}=\mathbf{. 7 9 5}$ & Total & $\mathbf{4 6 . 7 2 0}$ & $\mathbf{5 9}$ & & & \\
\hline
\end{tabular}

$\mathrm{F}(2,47)=96.207, \mathrm{~F}-\mathrm{tab}=3.18, \mathrm{DW}=1.005, \mathrm{P}<0.05$ 